\title{
Integrating Manufacturing, Management and Marketing into International Service Learning
}

\section{Dr. Ismail Fidan, Tennessee Technological University}

Dr. Ismail Fidan is a faculty member at the College of Engineering of Tennessee Technological University. His research and teaching interests are in additive manufacturing, electronics manufacturing, distance learning, and STEM education. Dr. Fidan is a member and active participant of SME, ASME, IEEE, and ASEE. He is also the Associate Editor of IEEE Transactions on Components, Packaging, and Manufacturing Technology.

\section{Dr. Bonita Barger, Tennessee Technological University}

Dr. Bonita Barger is currently an associate professor of Management at Tennessee Technological University. She is perceived as an innovative professional with diverse domestic and international operations experience in both for-profit and non-profit organizations. She has consistently demonstrated an ability to conceptualize and implement effective strategic human resource management plans that further broaden corporate objectives.

\section{Dr. Ersel Obuz, Celal Bayar University}

Dr. Ersel Obuz is a faculty member of Bioengineering Department at the Faculty of Engineering, Celal Bayar University, Manisa, Turkey. His areas of research are mainly mathematical and statistical modeling, fresh and processed meat products, biodegradable films, an unit operations in food engineering. His teaching interests are statistics, heat transfer, unit operations in food engineering, bioseparations and experimental design.

\section{Dr. S. Murat Bagdatli, Celal Bayar University}

Dr. S. Murat Bagdatli is a faculty member of Mechanical Engineering Department at the Faculty of Engineering, Celal Bayar University, Manisa, Turkey. His areas of research are mainly modeling of nonlinear systems, linear/nonlinear vibrations in mechanical systems, experimental linear/nonlinear vibrations, and perturbation methods. His teaching interests are dynamics, mechanical vibrations, and automatic control.

\section{Dr. Ismet Anitsal}

Dr. Ismet Anitsal is Faye Halfacre Moore Professor of Entrepreneurship and Associate Professor of Marketing at Tennessee Tech University. His research interests focus on customer productivity and customer value in services marketing and retailing, specifically at technology-based self-service environments. Dr. Anitsal is the current editor of Journal of Entrepreneurship Education and a past President of Atlantic Marketing Association.

\section{Dr. Meral Anitsal}

Dr. Meral Anitsal is an associate professor of Marketing at the College of Business - Tennessee Tech University. Her research and teaching interests include new product/service development, customer value, services marketing, and marketing research. She is focused on developing higher education courses that integrate multiple disciplines. She is a member and active participant of AMA, AMTP, SMA, Allied Academies and a past president of Atlantic Marketing Association. 


\title{
Integrating Manufacturing, Management and Marketing into International Service Learning
}

\begin{abstract}
In this endeavor, hands-on engineering and business courses have been combined into a newly generated interdisciplinary course, which is called International Service Learning (ISL). Teaching and learning strategies were integrated into the community projects so that the topics covered in lectures are practiced and solidified throughout the service learning projects. Four faculty members from the Manufacturing, Management and Marketing (3M) fields offered this cross-disciplinary and hands-on ISL course in Spring 2012 and 20 students enrolled from the college of engineering and college of business of Tennessee Tech University (TTU). The course was offered with on-ground and on-line components, and it was managed using the Desire2Learn (D2L) and Turnitin course management systems. Faculty members covered the 3M topics during the semester and took their students to Celal Bayar University (CBU), Turkey for almost 20 days for the study-abroad component of the course. Four teams were formed to work on various service learning projects with components in design, modeling, manufacturing, marketing, testing and packaging. This paper reports the accomplishments and findings of this project from the manufacturing perspective.
\end{abstract}

\section{Overview}

Service learning is becoming one of the most popular teaching and learning techniques in U.S. universities. Students solve real-world problems, build character and support the community activities via their coursework projects. ISL combines academic studies, volunteer service and full cultural immersion to give students a deeper, more meaningful study abroad experience. This initiative provides the linkage between service learning, cultural immersion and the creation of a global learning community [1].

In Spring 2012, ISL course was offered to help students enhance and increase their skills in teamwork, communication, critical thinking and real world problem solution. To solve the communication barriers during the course delivery, the active learning technologies employed were a hybrid model of on-ground traditional classroom sessions supported by D2L and Turnitin with virtual online teams comprised of students from various majors. The goal was to simulate Peter Senge’s learning organization model of building a shared vision, team learning, personal mastery, systems thinking and mental models [2].

Students' progress on learning to solve problems, think critically and work on teams in culturally diverse settings was evaluated by faculty and external international judges throughout every stage of the project, ultimately during final presentations. Students were also asked to complete a short survey provided by the Quality Enhancement Plan (QEP) Director that included questions 
modeled on several items from the National Survey of Student Engagement that relate to critical thinking, real-world problem solving, service learning and service to the community [3].

\section{Manufacturing Service Learning Projects}

Manufacturing related service learning projects have been completed at TTU in the past. Computer Aided Design, Rapid Prototyping and Computer Numerical Control courses teach the fundamentals of 2D/3D design and the generation of machining codes. In these courses, a required team project component enables students to solidify their learning in a societal and/or technical problem. Student teams have worked with various public schools and community organizations. Teams designed, built, machined and created a number of tools, gadgets, components and instruments for these organizations. Figure 1 shows a sample domestic service learning project. In this project, the team presents various science laboratory components built for the Algood Middle School located in Cookeville, Tennessee [4].

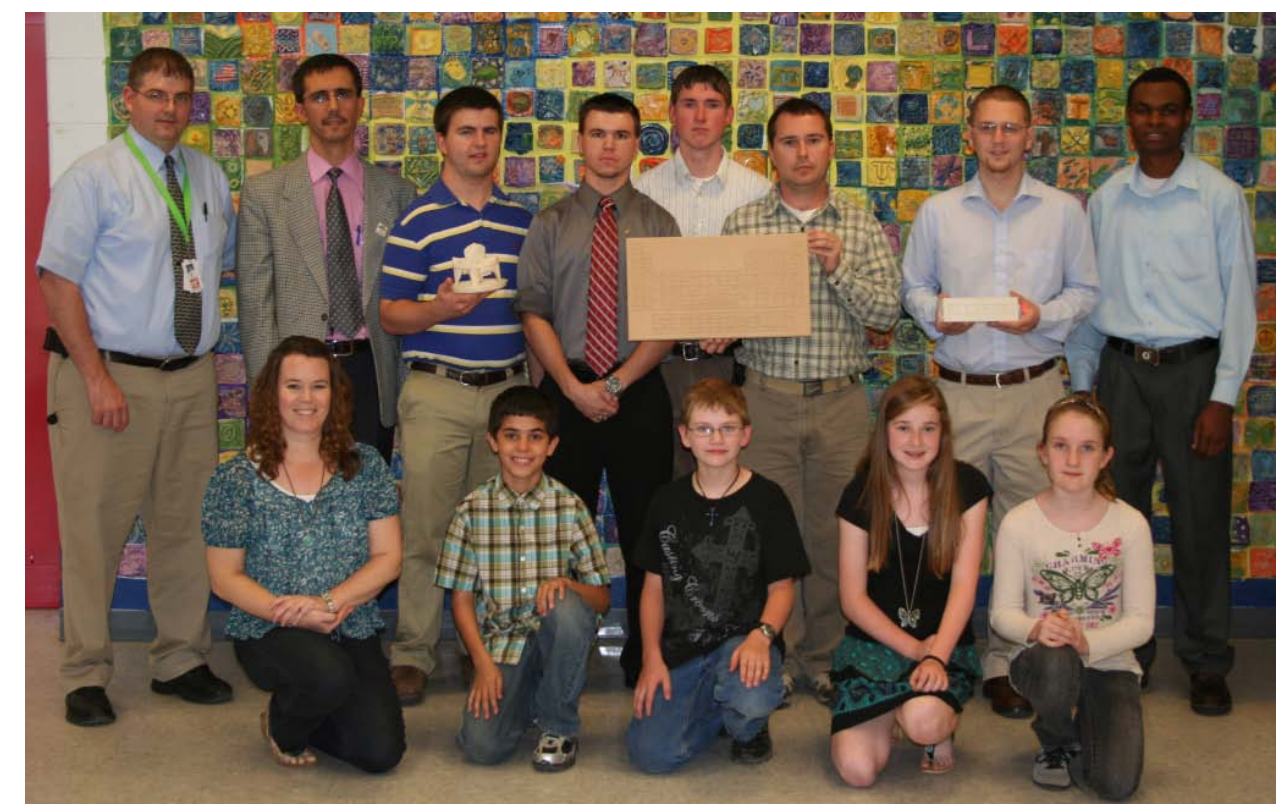

Figure 1: Science Laboratory Components manufactured for a Public School

A similar path was followed in ISL course. This time, the course was enhanced with marketing and management components other than the design and manufacturing contents. Students learned the Google Sketchup solid modeling software, 3D Printing technologies and CNC code generation via CNCez software tool. Hands-on laboratories were made in Sketchup, 3D Printing and CNC in Spring 2012. Specific ISL projects were assigned to four student teams: Leblebi (Turkish chick-pea), Mesir Macunu (mesir paste), Zeytin Yagi, (Turkish olive oil) and Buzlu Cay (Turkish iced tea). These specifically picked products were selected with the help of CBU faculty members. Beginning Spring 2012, students from TTU and CBU worked jointly to develop various marketing strategies and promotional tools to introduce these products into the U.S. market. Onsite actual tests and production facility visits were made during the CBU visit held in May 2012. Figure 2 shows an ISL student practicing the ceramic model preparation for a possible product package mockup held at Art Ceramics, Selcuk, Izmir. 


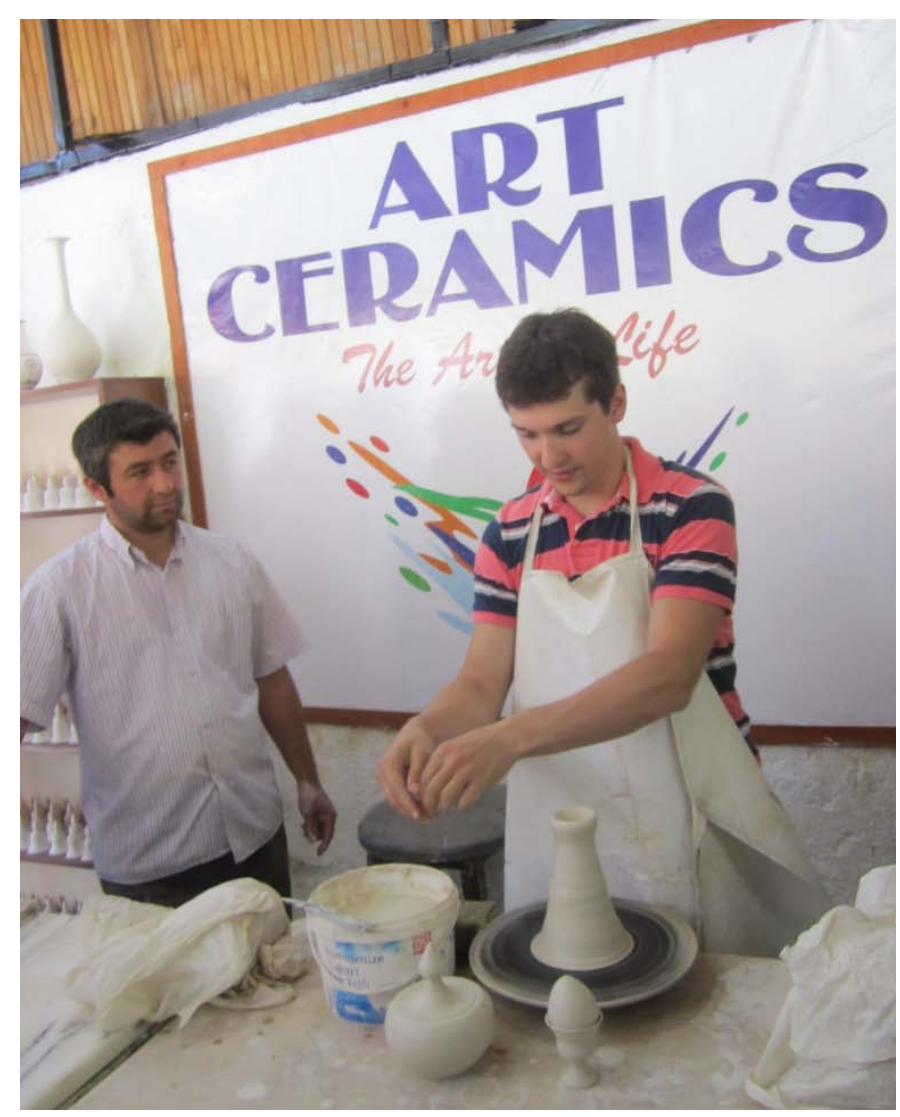

Figure 2: One ISL student practicing to learn a Ceramic Package Production in Turkey

\section{Mesir Paste Project}

In this section, Mesir Paste project will be singled out for an in-depth analysis, description and discussion. Mesir Paste, a traditional Turkish product with strong national ties, is as unique as the people who make up the country of Turkey. It consists of 41 natural herbs and spices that combine to create a flavorful, unique and healthful. Mesir comes in an assortment of forms including both liquid and solid varieties, from a viscous, honey-like material to a taffy-like substance. Mesir is a viable substitute for unhealthy snack foods and a new option in energy supplements [5]. The overall objective of the ISL research team is to create a marketing plan for Mesir products and to design new packaging for the United States market, while developing student skills of critical thinking, creativity, and teamwork.

The research team consisted of five students; two engineering and three business students, and a faculty member. Their task was to develop a product marketing strategy to promote the Mesir Paste to the US market, come up with a business management plan to introduce the product to US consumers and produce an innovative design and end-product to package the Mesir Paste to the US marketplace [6]. The course had a required two weeks hands-on, on-site component held at CBU. The student team spent its May 16 to June 1 timeframe in Turkey. They saw the culture, market, product, production and specific details while they were in Turkey. Myers \& Briggs Type Indicator methodology was used to identify strengths and weaknesses of team members. And, the work assignments have been distributed based on the findings of the Myers and Briggs Test [7]. 
Students learned details of 3M concepts during the Spring 2012 ISL course, which was held twice a week. Two food engineering students and two engineering faculty members from CBU also helped and supported the project deliverables. This course was a hybrid course offered through D2L system, and members of both universities were able to access the course materials, discussion ports, emails and assessment links. To get more information about Mesir products for US consumers, one beta testing opportunity was organized during TTU's Window on the World International Festival (http://orgs.tntech.edu/wow/). Mesir paste samples were purchased from Tulumba Company (http://www.tulumba.com/), and qualitative and quantitative data were collected from US visitors after they tasted the sample Mesir products [8]. Team members then conducted on-site visits and investigations while at CBU. They have compiled their works into a team report and project presentation, and all these materials were submitted to team faculty at the end of May 2012.

This course was a new initiative for both universities, and it had a number of original concepts. They are summarized as follows:

- Engineering and business students got together to find a unique solution to market an unknown product to US consumers. The specific product discussed in this initiative was Mesir Paste.

- The course included an online, on-ground, hands-on laboratory plus guest lectures and international site visit components. Two students and two faculty members from the CBU college of engineering were able to access most of these components.

- Assessment and evaluation components were handled with D2L and Turnitin software tools so that students learned fundamentals of work ethics and plagiarism.

- One objective of the course was to increase the students' skills in critical thinking, creativity and real world problem solution, the essential components of university QEP direction. The deliverables of the course had these QEP elements in lecture, laboratory and project phases. Course evaluation results will be given in the upcoming section.

- The student team learned to run a team-based research project. They developed a disciplinary action policy and individual assignments based on the Myers\&Briggs test findings.

- The team focused on the development of an environmentally friendly, healthy and offthe-shelf packaging product. The developed products and ideas were benchmarked to currently available US products like Laffy Taffy.

- The team proposed an offer and future work to develop two different types of new products for children and adults. They could be developed based on the ingredients and sugar level.

- Turkey is one of the developing countries located at the connection of Asia and Europe. The team visited INVEST (http://www.invest.gov.tr/) which is an organization tasked to investment support and promotion. Visiting such an organization helped the team develop 
a cutting edge business plan for the Mesir product.

- Turkish and American cultural interaction was another great outcome of this initiative. Both student and faculty teams worked and collaborated jointly for the full success of the project.

ISL course was a new initiative successfully organized and operated by TTU. Students and faculty jointly worked with their counterparts in CBU. The Mesir Paste research group successfully completed its tasks and deliverables in the Spring 2012 semester. Then, a student and faculty team from CBU came to TTU in June of 2012. The team completed volunteer work on the Free Hill Community Center's on-going maintenance projects. The center is a century old and a historically black community's educational and social gathering site.

Mesir Paste is a unique product with a traditional background, giving it a good chance of standing out among the vast amount of snack food choices currently in the United States market. In addition, it is relatively cheaper than its closest potential competitors, such as Laffy Taffy, and healthier in comparison. These characteristics provide a promising consumer value while also being easy to make and gaining a high profit margin. Mesir does have some weaknesses, however. The fact that it is an international product will automatically cause a lack of interest in some United States consumers. The small variety of flavors does not help this issue, leading to a slow or non-existent reputation growth. For the business, import tariffs and shipping costs present another weakness, as well as the ease of replication should the flavor become desired.

In the US there is a growing demand for healthier snack choices and an ever growing health consciousness, and Mesir Paste has the potential to meet that demand. The possibility for expansion into new markets is another major opportunity for this product. While attempting to share cultural values across the globe, Mesir Paste can grow an already expansive industry into untapped consumer markets.

\section{Project Evaluation}

In the pre-test, ISL students were asked to describe their progress on various objectives in a typical class setting. On the post-test they were asked about their progress on those objectives in the current ISL class. Although all students have completed the pre-test, the number of the students completing the post-test was only fourteen.

In the pre-test (Questions 1-19), students were asked: "Please think about your previous educational experience when you answer the questions. For each of the learning objectives listed, describe the amount of progress you made in a typical course." Choices ranged from No Progress (1) to Exceptional Progress (5). For questions 20-22, students were asked: "Please indicate your level of agreement with each of the questions for a typical course in your previous educational experience." Choices ranged from Strongly Disagree (1) to Strongly Agree (6). 
Table 1: Pre- and Post-Assessment data received from the ISL course students

\begin{tabular}{|c|c|c|c|c|c|c|}
\hline Item & $\mathbf{N}$ & $\begin{array}{l}\text { Pre } \\
\text { Mean }\end{array}$ & $\begin{array}{l}\text { Post } \\
\text { Mean }\end{array}$ & Mean & $\begin{array}{c}\text { Std. } \\
\text { Deviation }\end{array}$ & $\begin{array}{l}\text { Std. Error } \\
\text { Mean }\end{array}$ \\
\hline $\begin{array}{l}\text { 1. Separate factual information from } \\
\text { inferences. }\end{array}$ & 14 & 3.14 & 3.71 & -.571 & 1.089 & .291 \\
\hline 2. Identify inappropriate conclusions. & 14 & 3.14 & 3.64 & -.500 & 1.019 & .272 \\
\hline $\begin{array}{l}\text { 3. Understand the limitations of } \\
\text { correlational data. }\end{array}$ & 14 & 3.14 & 4.07 & -.929 & 1.072 & .286 \\
\hline $\begin{array}{l}\text { 4. Identify evidence that might support or } \\
\text { contradict a theory or hypothesis. }\end{array}$ & 14 & 3.43 & 4.07 & -.643 & .929 & .248 \\
\hline $\begin{array}{l}\text { 5. Identify new information that is needed } \\
\text { to draw conclusions. }\end{array}$ & 14 & 3.36 & 4.14 & -.786 & .893 & .239 \\
\hline $\begin{array}{l}\text { 6. Separate relevant from irrelevant } \\
\text { information. }\end{array}$ & 14 & 3.57 & 4.14 & -.571 & 1.158 & .309 \\
\hline 7. Learn and apply new information. & 14 & 3.57 & 4.14 & -.571 & 1.505 & .402 \\
\hline $\begin{array}{l}\text { 8. Interpret numerical relationships in } \\
\text { graphs. }\end{array}$ & 14 & 3.29 & 3.43 & -.143 & 1.406 & .376 \\
\hline $\begin{array}{l}\text { 9. Use mathematical skills to solve real- } \\
\text { world problems. }\end{array}$ & 14 & 3.29 & 2.93 & .357 & 1.336 & .357 \\
\hline $\begin{array}{l}\text { 10. Analyze and integrate information from } \\
\text { separate sources to solve a complex } \\
\text { problem. }\end{array}$ & 14 & 3.29 & 4.07 & -.786 & 1.122 & .300 \\
\hline $\begin{array}{l}\text { 11. Recognize how new information might } \\
\text { change the solution to a problem. }\end{array}$ & 14 & 3.36 & 4.00 & -.643 & 1.008 & .269 \\
\hline 12. Communicate effectively. & 14 & 3.79 & 4.07 & -.286 & 1.204 & .322 \\
\hline 13. Think critically. & 14 & 3.57 & 4.07 & -.500 & 1.092 & .292 \\
\hline 14. Think creatively. & 14 & 3.57 & 4.00 & -.429 & 1.158 & .309 \\
\hline 15. Solve real-world problems. & 14 & 3.14 & 4.29 & -1.143 & 1.231 & .329 \\
\hline 16. Effectively learn on your own. & 14 & 3.50 & 4.14 & -.643 & 1.277 & .341 \\
\hline $\begin{array}{l}\text { 17. Analyze and critically evaluate other } \\
\text { perspectives. }\end{array}$ & 14 & 3.50 & 4.36 & -.857 & 1.460 & .390 \\
\hline 18. Make effective decisions. & 14 & 3.50 & 4.07 & -.571 & 1.158 & .309 \\
\hline $\begin{array}{l}\text { 19. Work effectively with others as a } \\
\text { member of a team. }\end{array}$ & 14 & 3.50 & 4.29 & -.786 & 1.311 & .350 \\
\hline $\begin{array}{l}\text { 20. The typical course you have taken has } \\
\text { mainly emphasized memorizing } \\
\text { information. }\end{array}$ & 14 & 4.50 & 2.21 & 2.286 & 1.729 & .462 \\
\hline $\begin{array}{l}\text { 21. The typical course you have taken has } \\
\text { involved students in active learning rather } \\
\text { than solely depending on lectures. }\end{array}$ & 14 & 4.00 & 5.57 & -1.571 & 1.158 & .309 \\
\hline $\begin{array}{l}\text { 22. The typical course you have taken has } \\
\text { encouraged you to get involved in } \\
\text { improving your community. }\end{array}$ & 14 & 3.36 & 4.36 & -1.000 & 1.797 & .480 \\
\hline
\end{tabular}

In the post-test, the response options were the same, but the instructions were changed to read: "For the following learning objectives we would like you to evaluate your experience with this class or project. Describe the amount of progress you made on each objective" and "Please indicate your level of agreement with each of the questions as they relate to this course or 
project." As can be seen from Table 1, the results of the survey instrument indicate that ISL students gained excellent skills in key QEP components.

\section{Conclusions}

The ISL initiative reported in this paper provides valuable experiences to students in societal and global issues while they learn and practice their current curricular concepts in 3M. In the current ISL practice, intercultural understanding and international experiences in business and engineering fields helped students widen their perspectives in 3M. The assessment data received from the students also proved that students gain invaluable skills in key QEP factors.

\section{Acknowledgements}

This project has been made available through a grant from the QEP program of TTU and matching funds of CBU. The support and contribution of both universities and course students are greatly appreciated.

\footnotetext{
Bibliography

${ }^{1}$ http://www.servicelearning.org/what-service-learning, accessed on March 15, 2013.

${ }^{2}$ Jackson, B. G. (2000). A Fantasy Theme Analysis of Peter Senge’s Learning Organization, Journal of Applied Behavioral Science, vol. 36 issue. June no. 2 pp. 193-209.

${ }^{3}$ http://www.tntech.edu/qep/home/, accessed on March 15, 2013.

${ }^{4}$ Tech students are in action to support regional science education, Herald-Citizen, May 22, 2011, http://iweb.tntech.edu/ifidan/STEM\%20INITIATIVE.htm, accessed on March 15, 2013.

${ }^{5}$ Oskay, M. (2010). Determination of Some Chemical Parameters and Antimicrobial Activity of Traditional Food: Mesir Paste. Journal of Medicinal Food, 13(5), 1195-1202. doi: 10.1089/jmf.2009.0209.

${ }^{6}$ Annacchino, M. A. (2007). The Pursuit of New Product Development. Mason, Ohio: Butterworth- Heinemann.

${ }^{7}$ Myers, I \& Briggs, K MBTI Basics. (n.d) accessed on March 15, 2013, from The Myers \& Briggs Foundation Web Site: www.myersbriggs.org

${ }^{8}$ http://www.youtube.com/watch?v=B_bT8Rx9i6g, accessed on March 15, 2013.
} 